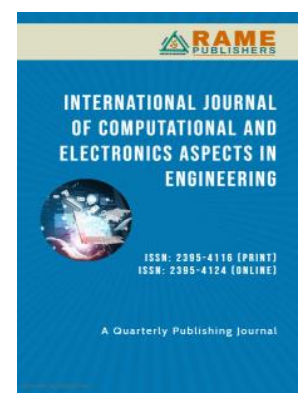

Saurabh Zilpe ${ }^{1}$ saurabhzilpe3000@gmail.com

Jagdish Pardhi' jpardhi1999@gmail.com

Tejasvini Pund ${ }^{\mathbf{1}}$ pundteju1998@gmail.com

Rupesh Choudhari ${ }^{1}$ rupesh.choudhari110@gmail.com

Department of Information Technology, Smt. Radhikatai Pandav College of Engineering, Nagpur, India

\title{
E-Ration System Using QR Code
}

Abstract - In a growing and develop country like India specifically, Ration card is the important documents which poor people need. All the people having a ration card to buy the various materials (sugar, rice, oil, kerosene, etc.) from the ration shops which are funded by government. But as we know due to increasingly corruption and commercialization, it's becoming challenging day by day for people to get a hold of goods and stuffs what government sends in the same quality and quantity. In current scenario, this system is having two drawbacks. Firstly, the weight of the material may be inaccurate and inappropriate due to human manual mistakes and secondly, if we do not buy the goods and materials by the end of the month, they will re-sale to others without any intimation to the government and consumers. In this project, propose Automatic Ration Materials Distribution based on GSM (Global System for Mobile) and QR-code.

Keywords - E-Ration, Fraud, QR code, Commercialization, Smartphone, Web Application, Scanner, Reader.

\section{INTRODUCTION}

FPS (Fair price Shop) shopkeeper, PDS (Public Distribution System) i.e., actors in ration management system. Main goal to develop this system for Shopkeeper, Beneficiary and government also. This system eases ration distribution system with minimum cost required. The customer can easily refer all the details about product and they can to buy. There is no way to wait for queue and wasting time in ration shop. In this system traditional ration card is replace by smart card. In order to make efficient and improve the current system of PDS implemented E-Ration with Biometric device. Using this device identity of card holder and their information can be easily available. The finger print of the citizens is already in the database of Andhra Card, a positive match can be ensured each time the consumer visits the FPS. Shopkeeper have this application which makes eases work of beneficiary as well as Shopkeeper [1,2].

Technical Article

First Online on -8 June 2021

\section{(C) 2021 RAME Publishers}

This is an open access article under the CC BY 4.0 International License https://creativecommons.org/licenses/by/4.0/

Cite this article - Saurabh Zilpe, Jagdish Pardhi, Tejasvini Pund, Rupesh Choudhari, "E-Ration System using QR Code", International Journal of Computational and Electronic Aspects in Engineering, RAME Publishers, vol. 2, issue 2, pp. 10-13, 2021.

https://doi.org/10.26706/ijceae.2.2.20210405
Computerization can help in modernizing the FPS.Eration-The aim of this project is to developing a better, efficient ration card system using SMART CARD. The proposed system is very useful to users, shopkeeper as well as government also. Shopkeeper have this android application, so it is easy to use and hence it reduces cost. By using website beneficiary can check their ration details by using ration id. SMS notification contains the confirmation message of commodity lifted by customer and also short URL for complaint purpose.

\section{Method And MATERIAL}

\section{A. Existing software}

In existing system, as soon as beneficiary understand that our monthly ration is available on shop after that beneficiary go to shop with their traditional ration card which need to renew after 1-2 years. Beneficiary take that card and waiting on queue. when his/her turn comes, he gives his ration card to shopkeeper and shopkeeper have a E-PoS (Electronic Point-of-Sale) machine do entry on that and according to card type commodity give to beneficiary, and shopkeeper also make entry on his register also. After that shopkeeper take sign of beneficiary and given receipt accordingly. Then payment is done. In existing system, Beneficiary unknown about available stock [3,7]. 


\section{B. Proposed System}

In proposed work is first of all we are going to make use of E-government technology that is being implemented in almost every area of government administration. Corruption and degradation of quality of goods would be using E-Rationing system. User would be registering online using personal credentials and information as registered. Also, family information needs to be given as input while registering. Thus, each time whenever the person gets notification about goods and services delivered, he needs to go through the verification process to prove he is the authorized person. Once verification is completed successfully, he can collect the quantity as logged into the system. Using QR code, it will be possible to uniquely build a module for each customer. As well as we are going to develop complaint portal where user can register the complaint against the Distributor if he is providing bad quality food [5-6].

\section{Advantages of Proposed System}

- Transparency between government, consumer and distributors.

- Using QR code, consumers can view the quality and quantity of goods assigned to them.

- Consumers can register complain if found fraud by distributor.

- The authentication of the customer can also be checked by taking his finger print and getting it scanned through the RFID module which has stored his/her finger prints for that ration shop.

- Load cell and many other sensors can be added for improving the accuracy and reliability. A local and central server can be added, which can be monitored.

- If more stations are added the users can withdraw the goods from anywhere. v. Hardware and software can be upgrade according to requirement.

- If storage is big, it can serve many people. vii. We can use bio-sensors to check the quality of ration commodities [8].

\section{MOdulE OF E-RATIO SySTEM}

A. Module 1- Public Distribution System (Admin Portal)

In this module there will be one web application where PSD system can give stock to shopkeeper and also able to track the inventory.

- Login Module - Admin can login

- Track Inventory Module - Admin can track the food stock inventory and history inventory of any shopkeeper

\section{B. Module 2-Shopkeeper Module}

In this module there will be one android application and this app will used by shopkeeper and used for tracking, allocation, scanning customer QR code.

- Login Module - Shopkeeper can login

- Track Inventory Module - Shopkeeper can track the food stock and what quantity is available at their shop and history of previous stock as well.

- Scan QR code - This module will use to scan the customer qr code.

- Customer Family details - This module will be going to use for view the family member and stock details of customer.

- Transaction Module - Able to view transaction

\section{Module 3-Customer Module}

In this module there will be one android application for the end user i.e., customer and this app will used for tracking order, stock availability, view notification send by shopkeeper.

- Login Module - Customer can login

- Stock Availability - Customer can live check the available stock of ration shop and its quantity.

- Show QR code - This module will use to show the customer QR code.

- Customer Family details - This module will be going to use for view the family member and stock details of customer.

- Transaction Module - Able to view all transactions 


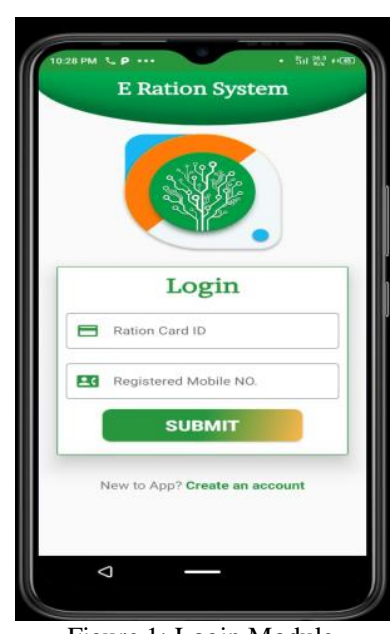

Figure 1: Login Module

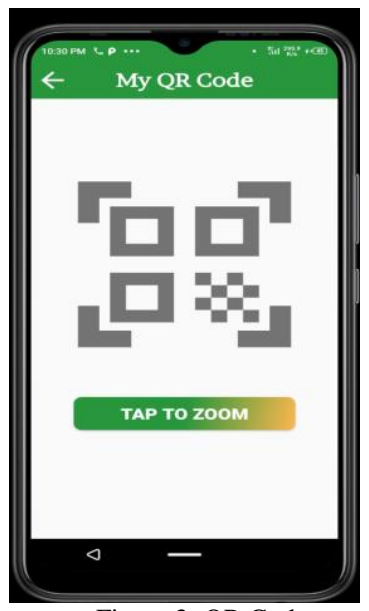

Figure 3: QR Code

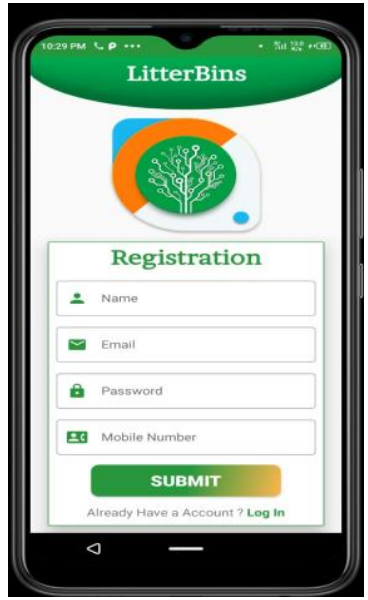

Figure 2: Registration

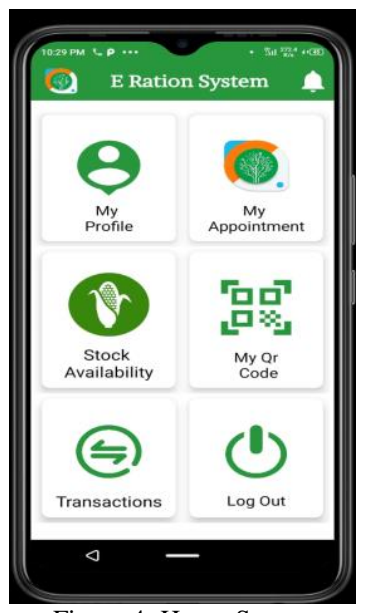

Figure 4: Home Screen

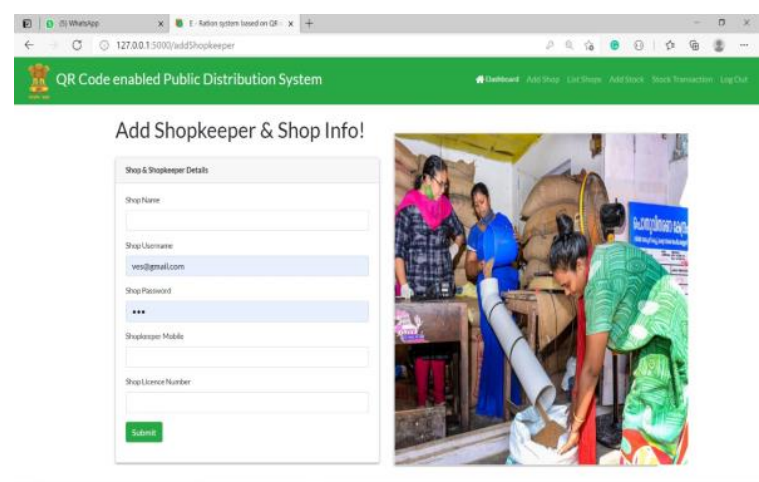

Figure 5: Admin Module

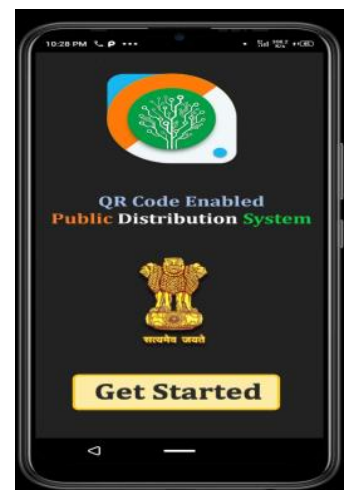

Figure 6: Home Page Session

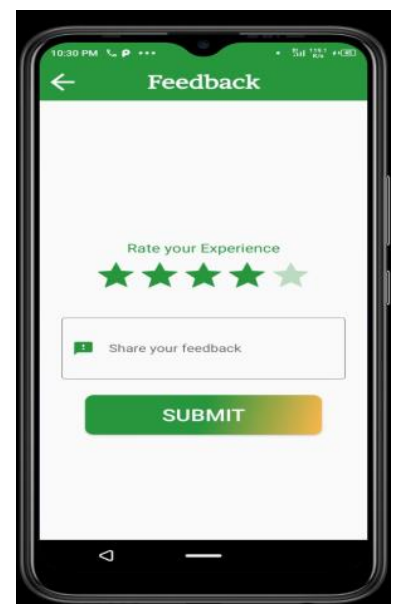

Figure 7: Customer Feedback

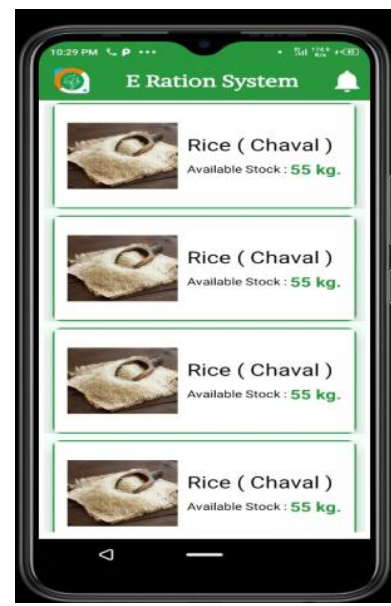

Figure 8: Customer Ration Stock

\section{SYSTEM ARCHITECTURE}

\section{A. Design Description}

Collector have all rights to control the system. Collector allocate work to tahsil officer then tahsil officer have control on distributors. Citizens take their ration to their ration shop. If citizen have any issue, then citizen write his complain in complain box which is read by collector and collector work on complain [4]. All the records by distributor are given back to tehsil officer and tahsil officer give report to collector.

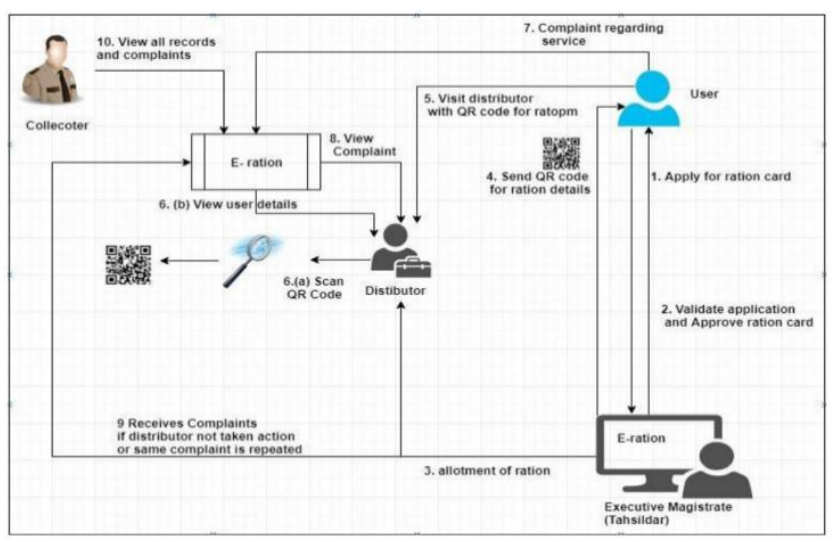

Figure 9: System architecture

\section{CONCLUSION}

In order to make it efficient and improve the current system of PDS we are implementing e-Ration System. In this we are going to purpose an android app for customer and shopkeeper and web application PDS system.

In this there will be Web Portal (Admin) where whenever PDS department will supply the food item stock to the shopkeeper that time they will update the stock on web portal as well so that we they can easily track the 
supply quantity of food and with this we can remove the chances for fraud.

Then there will be an Android App (User) for shopkeepers where they will get immediate notification when PSD department supply the food and they can easy tack the Inventory and validate to food quantity and size.

There will be one more Android App (End User) which is for the customer there the customer can easily check food stock available at ration shop or and also able to check the price of food and available quantity of food at ration shop and with this app customer will able to see its previously buy food transaction details and family details and they will also have one QR code in this app.

\section{ACKNOWLEDGMENT}

The authors acknowledgement the support of Samyak Bhalerao and Dinesh Heribhau. The authors also thank to Dietrich Ayala, Priyanka Nag, Aman Sehgal and the Mozilla community for their immense support.

\section{REFERENCES}

[1] V. Singh, V. Aamani, and B. Mounika, "Smart Ration Card", Journal of Global Research in Computer Science, vol. 4, no. 4, pp. 172-174, April 2018.

[2] Dhanashri Pingale, Sonali Patil, Nishigandha Gadakh, Reena Avhad, and Gundal S.S, "Web Enabled Ration Distribution and Corruption Controlling System," International Journal of Engineering and Innovative Technology (IJEIT) Volume 2, Issue 8, February 2013.

[3] Ministry of Consumer Affairs, Food and Public Distribution Department of Food and Public Distribution, Annual Plan 2011-12.

[4] Neha Pardeshi, Trupti Desale, Prajakta Bhagwat, and Ruchali Ahire, "Web-Enabled Ration Distribution and Controlling," International Journal of electronics, Communication \& Soft Computing Science \& Engineering, March 2019.

[5] Rajesh C. Pingle and P. B. Borole, "Automatic Rationing for Public Distribution System (PDS) using RFID and GSM Module to Prevent Irregularities," HCTL Open International Journal of Technology Innovations and Research, vol. 2, pp.102-111, March 2017.

[6] T. R. Sreenivas, "A case of supply chain management of Public Distribution System operations in the Chhattisgarh state of India," in 3 - 7 September 2012.

[7] Mahammad Shafi, K. Muni Dhanalakshmi, "e_Ration Shop: An Automation Tool for Fair Price Shop under the Public Distribution System in the State of Andhra," IJCA Proceedings on National Conference on Computational Intelligence for Engineering Quality Software, 2

[8] A. N. Madur, Sham Nayse, "Automation in Rationing System Using Arm 7," International Journal of Innovative Research in Electrical Electronics, Instrumentation and control engineering, vol. 1, no. 4, July 2018. 